Kwiatkowska, J. (2018). Cross-selling and up-selling in a bank. Copernican Journal of Finance \& Accounting 7(4), 59-70. http://dx.doi.org/10.12775/CJFA.2018.020

\author{
JULIA KWIATKOWSKA* \\ Nicolaus Copernicus University in Toruń
}

\title{
CROSS-SELLING AND UP-SELLING IN A BANK
}

Keywords: cross selling, up selling, unethical sale.

J E L Classification: G21, G40, K4.

\begin{abstract}
Increasing competition on the banking market, as well as the desire to achieve maximum profits, means that banks are increasingly looking for methods that will allow them to increase sales. One of them turned out to be sales techniques such as cross selling and up selling, which undoubtedly increase the bank's profit. In addition, cross-selling contributes to building a larger product portfolio of the client, which binds it more strongly to the bank and minimizes the risk of the customer moving to a competitive entity. However, the use of these sales techniques also entails risks. One of them is the loss of a good image. The aim of the article is to present the results of an own study on the use of cross-selling and up-selling by banks and influence on their image. Additionally, the article presents the essence and way of functioning of cross-selling and up-selling, which are used by financial institutions in the pursuit of profit maximization. The results of the study confirmed that the results of the application of these sales techniques turns out to have a negative impact on the customer's perception of the bank. Both cross-selling and up-selling contribute to the dissatisfaction of customers, which often leads to the loss of their part in favor of a competitive bank. In addition, the negative perception of the bank undermines its image, which is an important element in such a strong competition.
\end{abstract}

Date of submission: March 7, 2019; date of acceptance: April 26, 2019.

* Contact information: 502989@doktorant.umk.pl, Nicolaus Copernicus University in Toruń, Gagarina 13a, 87-100 Toruń, Poland, phone: +48 5661146 34; ORCID ID: https://orcid.org/0000-0003-1791-7512. 


\section{INTRODUCTION}

The goal of financial institutions is to achieve the greatest financial performance. Banks and loan companies, insurance companies and financial intermediaries are focused on generating profit. There are many banks on the Polish financial market, which results in strong competition between them. The situation is also not facilitated by the fact that they deal with the distribution of the same products that differ only by individual parameters. In connection with the above, financial institutions are looking for solutions that will enable them to achieve their intended results and maintain a competitive position on the market. In addition to traditional activities, which include training of employees, improving products, taking care of the image and a wide range of advertising, there are variety of modern sales techniques. These techniques include cross selling and up selling, which allow them to maximize profit from one customer. Historically, financial institutions were focused on acquiring new clients. Currently, it is more important for them to keep existing customers and enrich their with new products. The aim of this action is not only to provide a strong relationship that will bind the client to the institution, but also to maximize profit. It results mainly from increased sales of products and low costs of acquiring new customers.

\section{THE RESEARCH METHODOLOGY AND THE COURSE OF THE RESEARCH PROCESS}

The aim of the article is to present the results of the own study on the use of cross-selling and up-selling by banks and influence on their image. It is worth stressing that this is the first study on the use of cross-selling and up-selling by banks. The question of how the use of these techniques affects the bank's perception and what customers think about them has never been discussed before. This is a high value of the study, and the results allow us to draw conclusions regarding certain trends and opinions among bank clients. This study was conducted in April 2018 using an online questionnaire. It was addressed to people who were or are currently customers of at least one bank. The questionnaire consisted of a statement allowing to determine gender, age, education and place of residence of respondents, as well as 24 closed questions. The main objective of the study was to investigate whether the use of cross-selling and up-selling influences the perception of bank by its customers. Addition- 
ally, the article presents the result of the Cronbach's Alpha coefficient, which is a test verifying the reliability of used questionnaires, and more specifically its consistency. The results of Pearson's linear correlation coefficient were also presented to diversify the research. The relationship between gender and propensity to use the products offered in the discussed sales techniques was examined. Additionally, the article presents the essence and way of functioning of cross-selling and up-selling, which are used by financial institutions in the pursuit of profit maximization. Achieving this goal required the analysis of national and foreign source literature, which includes books, articles, reports and studies, as well as an analysis of legal regulations, among which legal acts are distinguished.

\section{STRATEGY AND SALES TECHNIQUE}

In domestic and foreign literature cross selling and up selling are defined in various ways. In one case, they are called sales strategies used to increase income (Johnson \& Friend, 2014). In the second one, they are presented as sales techniques that allow you to increase sales and income generated by the customer (Kubiak \& Weichbroth, 2010).

There are many definitions of strategies in the literature, but all emphasize the features that the strategy has a long time horizon and are based on the future. To talk about strategy, it is also important to remember that the actions taken by the company must be matched to its objectives (Supernat, 2000, pp. 13-14). In addition, the entity must indicate the methods for their implementation (Kaleta, 2013, p. 41).

By definition, which can be found in dictionaries, it follows that the technique is a procedure that brings the company closer to the goal. It also indicates the accompanying elements, that is the way in which activities are carried out, the interdependence and the rational selection of resources and means of action (Mikołajczyk, 1997, pp. 7-38).

For the purpose of the article, it was assumed that cross selling and up selling are sales techniques. Financial institutions use cross selling and up selling to maximize the profit that is the goal of their business. It can therefore be said that these are activities that contribute to the goal. In addition, these techniques are subject to a sales strategy, which in the case of financial institutions can be based, for example, on long-term revenue growth. 


\section{Cross SELLing}

Financial institutions, in order to maximize profit, use cross-selling techniques. Cross selling is otherwise called bundling. Cross selling is about offering customers additional products or services to the basic product they purchase. It is worth emphasizing that the products or services offered in this way are complementary goods. This means that they supplement each other. An example can be a laptop bought in the store and a bag that was offered as part of cross-selling. In financial institutions, such an example can be insurance, offered with a loan (Próchnicki, 2014).

The basic principle of cross-selling is the fact that an additional product or service is offered only when the customer has already purchased the basic product, but the purchase transaction has not yet been completed. That means it is not risky to offer complement goods because it is offered only when the basic product is purchased. Therefore, financial institutions are willing to use this technique to maximize profit (Baumgarten, Widz, Białokozowicz \& Dietl, 2006). Cross selling allows to increase sales per one customer and strengthen his or her bond. Cross selling is referred as the technique of maximizing profit generated by one customer. The use of this technique also reduces need to acquire new customers, and reduces the costs associated with it. Financial institutions are willing to use cross-selling due to the possibility of building a strong relationship with the customer, which will reduce the risk related to the loss of the customer in favor of the competitive entity (Szczepaniec, 2003). The purposes of using cross-selling are (Paradecki, 2008, p. 343):

- increasing turnover while fixed costs are constant,

- increasing customer loyalty,

- reducing the clients' fluctuation,

- building a relationship with the client,

- optimal use of distribution channels,

- reducing uncertainty and risk.

\section{UP SELLING}

Another technique that maximizes profit is up selling. Up selling, also known as an additional sale, increases value of the product or service being sold. It consists in offering a product or service of the same nature, but with higher quality or greater functionality. The result is that the price of this product or ser- 
vice is much higher and allows company to earn more per each transaction. It should be emphasized that products and services sold as part of up-selling are substitute goods, which means that they substitute each other and meet the same needs. An example might be selling a laptop with better parameters than the one that the customer originally chose. In the case of financial institutions, among the up-selling examples, one can distinguish opening of a more expensive bank account with greater functionality and credit cards with a higher limit, the use of which accrues numerous discounts and benefits. However, the most popular up selling is used for the sale of savings products, because currently offered deposits and savings accounts are low-income products. Therefore, it is more convenient to buy structured deposits or investment funds (Próchnicki, 2014).

One of the principles of up-selling is the fact that it is used when the customer has not yet purchased the basic product and the purchase transaction has not ended. It means that the technique consists in proposing a product equipped with additional functions or higher quality than basic product that the customer was interested in. Financial institutions are less likely to use upselling because up selling is more risky than cross selling. An attempt to sell a more expensive product may discourage the customer enough that he or her will completely abandon this purchase. It is important that the sales process with this technique is carried out slowly and customer's reaction is observed (Próchnicki, 2014).

\section{GUIDELINES ON CROSS-SELLING PRACTICES}

In 2016, the European Securities and Markets Authority, ESMA, issued Guidelines on Cross-selling Practices. The main purpose of the document is to protect investors in EU countries. The guidelines are designed to develop a coherent and effective approach to the supervision of companies and to understand expectations in the field of standards and organizational solutions among institutions that use cross-selling.

The guidelines relate to the MiFID II Directive (Markets in Financial Instruments Directive), and therefore apply to offering investment products in combination with another product or service. However, the possibility of using this document when offering other products is not excluded, unless there are separate regulations that say differently. 
Table 1. ESMA guidelines on cross-selling practices

\begin{tabular}{|c|c|}
\hline Guideline 1 & $\begin{array}{l}\text { The guideline obliges to inform customers about the prices of sold packages and the in- } \\
\text { dividual prices of products making up the package. Moreover, institutions that use cross- } \\
\text {-selling should prepare summaries and summaries of all known and significant costs rela- } \\
\text { ted to the purchase of products both in the form of a package and separately. }\end{array}$ \\
\hline Guideline 2 & $\begin{array}{l}\text { The guideline obliges financial institutions to provide timely information about price and } \\
\text { costs so that the customer can make a decision about buying in a conscious manner. }\end{array}$ \\
\hline Guideline 3 & $\begin{array}{l}\text { The guideline obliges financial institutions to provide transparent and precise informa- } \\
\text { tion, as well as to use a simple language that will be understandable for each client. Ad- } \\
\text { ditionally, it obliges to display information about prices and costs of products included } \\
\text { in the package. }\end{array}$ \\
\hline Guideline 4 & $\begin{array}{l}\text { The guideline obliges institutions to provide information on prices and costs in such a way } \\
\text { as not to mislead customers and to hide real costs. In addition, information provided to } \\
\text { customers is to give the opportunity to compare costs with alternative products. }\end{array}$ \\
\hline Guideline 5 & $\begin{array}{l}\text { The guideline obliges institutions to provide information on non-price components and } \\
\text { risks that are associated with products purchased both in a package and separately. }\end{array}$ \\
\hline Guideline 6 & $\begin{array}{l}\text { The guideline obliges to display information on non-price elements and risk in a manner } \\
\text { no less visible than information on prices and costs, as well as to use a simple language } \\
\text { that is understandable to clients. }\end{array}$ \\
\hline Guideline 7 & $\begin{array}{l}\text { The guideline requires informing customers about the possibility of purchasing selected } \\
\text { products separately, not only in the form of a package. With this information, the custo- } \\
\text { mer is to decide consciously whether he will purchase the products in the package or } \\
\text { separately and whether it is necessary to purchase one of the component products. In } \\
\text { addition, the directive obliges institutions not to create an artificial impression that the } \\
\text { purchase of a package is mandatory, if in fact it is possible to purchase individual products } \\
\text { separately. }\end{array}$ \\
\hline Guideline 8 & $\begin{array}{l}\text { The guideline obliges institutions to train employees who will use cross-selling to familia- } \\
\text { rize them with the risks and the nature of bundling. }\end{array}$ \\
\hline Guideline 9 & $\begin{array}{l}\text { The guideline obliges to introduce the remuneration models in the form of incentives or } \\
\text { rewards received for responsible, fair treatment of clients. }\end{array}$ \\
\hline Guideline 10 & $\begin{array}{l}\text { The guideline obliges to inform about withdrawal periods when purchasing products se- } \\
\text { parately or in a package. In addition, it is proposed that these periods should be the same } \\
\text { for bundling and for selling products separately. }\end{array}$ \\
\hline
\end{tabular}

S o u r c e : own study based on: European Securities and Markets Authority, 2016.

\section{THE OUTCOME OF THE RESEARCH PROCESS AND CONCLUSIONS}

150 respondents took part in the survey. The whole group consisted of ex or current clients of at least one bank. The answers were obtained through the use of an online questionnaire. In order to reliably and reliably obtain information on the impact of cross-selling and up-selling on the perception of the bank by its clients, short definitions explaining the nature of the operation of both techniques are included in the questionnaire. Additionally, in order to verify the 
correctness of the questionnaire, the Cronbach's Alpha coefficient was used. It is a test examining the reliability of used questionnaires, specifically the internal coherence of the tool. In the study used, the Cronbach's Alpha coefficient was approximately 0.78 . This means that the questionnaire used in the study is highly consistent and reliable. All respondents declared that they were or are currently clients of the bank. In addition, they were in the age range between 18 and 60 years, which means that the study has reached younger and older customers. Over half of them live in a city of 200,000 to 500,000 inhabitants, and the most frequently indicated education is higher education. The characteristics of the respondents are presented in table 2 .

Table 2. The characteristics of the respondents

\begin{tabular}{|c|c|c|c|}
\hline Gender & $\begin{array}{c}\text { Woman } \\
\text { Man }\end{array}$ & $\begin{array}{l}74.7 \% \\
25.3 \%\end{array}$ & $N=150$ \\
\hline Age & $\begin{array}{l}\text { Up to } 20 \text { years (inclusive) } \\
\text { Over } 20 \text { years to } 30 \text { years } \\
\text { Over } 30 \text { years to } 40 \text { years } \\
\text { Over } 40 \text { years to } 50 \text { years } \\
\text { Over } 50 \text { years to } 60 \text { years } \\
\text { Over } 60 \text { years }\end{array}$ & $\begin{array}{l}4.7 \% \\
70 \% \\
10.7 \% \\
11.3 \% \\
3.3 \% \\
0 \%\end{array}$ & $N=150$ \\
\hline Place of residence & $\begin{array}{l}\text { Village } \\
\text { A city of up to } 200,000 \text { residents } \\
\text { A city of over } 200,000 \text { residents up to } 500,000 \\
\text { residents } \\
\text { City over } 500,000 \text { residents }\end{array}$ & $\begin{array}{l}30.9 \% \\
26.8 \% \\
32.2 \% \\
10.1 \%\end{array}$ & $N=149$ \\
\hline Education & $\begin{array}{l}\text { Basic education } \\
\text { Vocational education } \\
\text { Secondary education } \\
\text { Higher education }\end{array}$ & $\begin{array}{l}0.7 \% \\
2.7 \% \\
28.7 \% \\
68 \%\end{array}$ & $N=150$ \\
\hline
\end{tabular}

S o u r c e : author's own survey.

It is worth noting that the research was carried out on a targeted sample. This means that a non-random sampling of respondents to social research was made. This is due to the fact that the purpose of the study was not to examine the structures but to identify general trends in banking. The results of the survey were to show a certain tendency regarding the perception of cross-selling and up-selling in banks and help determine what customers think about them. To achieve the goal of the article, the answers to selected questions from the survey sheet were analyzed. These questions checked the level of customer knowledge on cross-selling and up-selling as well as the level of satisfaction 
with the products purchased in this way. Answers to these questions are presented in tables 3 and 4.

Table 3. Answers to selected questions - cross selling

\begin{tabular}{|c|c|c|c|}
\hline $\begin{array}{l}\text { Have you ever heard the concept of "cross sell- } \\
\text { ing"? }\end{array}$ & $\begin{array}{l}\text { Yes } \\
\text { No }\end{array}$ & $\begin{array}{l}48 \% \\
52 \%\end{array}$ & $\mathrm{~N}=148$ \\
\hline $\begin{array}{l}\text { Do you know what means and how does cross- } \\
\text { selling work? }\end{array}$ & $\begin{array}{l}\text { Yes } \\
\text { No }\end{array}$ & $\begin{array}{l}85 \% \\
15 \%\end{array}$ & $N=80$ \\
\hline Have you been offered products in this way? & $\begin{array}{l}\text { Yes } \\
\text { No }\end{array}$ & $\begin{array}{l}65.1 \% \\
34.9 \%\end{array}$ & $N=149$ \\
\hline $\begin{array}{l}\text { Have you ever used a product offered as part of } \\
\text { cross-selling? }\end{array}$ & $\begin{array}{l}\text { Yes } \\
\text { No }\end{array}$ & $\begin{array}{l}40.4 \% \\
59.6 \%\end{array}$ & $N=109$ \\
\hline $\begin{array}{l}\text { Are you satisfied with the product purchased as } \\
\text { part of "cross-selling"? }\end{array}$ & $\begin{array}{l}\text { Yes } \\
\text { No }\end{array}$ & $\begin{array}{l}49 \% \\
51 \%\end{array}$ & $N=49$ \\
\hline If you are not satisfied: why? & $\begin{array}{l}\text { Unattractive interest rate } \\
\text { The product turned out to be } \\
\text { different than offered } \\
\text { The product turned out to be } \\
\text { unnecessary } \\
\text { The product turned out to be } \\
\text { expensive }\end{array}$ & $\begin{array}{c}1 \\
5 \\
15 \\
10\end{array}$ & $\begin{array}{l}\mathrm{N}=23 \\
\text { (multiple } \\
\text { choice) }\end{array}$ \\
\hline $\begin{array}{l}\text { Has the use of "cross-selling" had a positive or } \\
\text { negative impact on your perception of a bank that } \\
\text { tried to sell its products in this way? }\end{array}$ & $\begin{array}{l}\text { Positive } \\
\text { Negative } \\
\text { It had no effect }\end{array}$ & $\begin{array}{c}16.3 \% \\
34.6 \% \\
49 \%\end{array}$ & $N=104$ \\
\hline $\begin{array}{l}\text { Has the use of "cross-selling" ever maked changed } \\
\text { the bank that you used? }\end{array}$ & $\begin{array}{l}\text { Yes } \\
\text { No }\end{array}$ & $\begin{array}{l}11.5 \% \\
88.5 \%\end{array}$ & $N=104$ \\
\hline $\begin{array}{l}\text { Do you think that cross-selling may infringe con- } \\
\text { sumer rights? }\end{array}$ & $\begin{array}{l}\text { Yes } \\
\text { No }\end{array}$ & $\begin{array}{l}48.6 \% \\
51.5 \%\end{array}$ & $N=144$ \\
\hline
\end{tabular}

S o u r c e : author's own survey.

Table 4. Answers to selected questions - up selling

\begin{tabular}{|c|c|c|c|}
\hline Have you ever heard the concept of "up selling”? & $\begin{array}{l}\text { Yes } \\
\text { No }\end{array}$ & $\begin{array}{l}37.2 \% \\
62.8 \%\end{array}$ & $\mathrm{~N}=148$ \\
\hline $\begin{array}{l}\text { Do you know what means and how does up- } \\
\text { selling work? }\end{array}$ & $\begin{array}{l}\text { Yes } \\
\text { No }\end{array}$ & $\begin{array}{l}78.5 \% \\
21.5 \%\end{array}$ & $N=65$ \\
\hline Have you been offered products in this way? & $\begin{array}{l}\text { Yes } \\
\text { No }\end{array}$ & $\begin{array}{l}37.4 \% \\
62.6 \%\end{array}$ & $\mathrm{~N}=147$ \\
\hline $\begin{array}{l}\text { Have you ever used a product offered as part of } \\
\text { up-selling? }\end{array}$ & $\begin{array}{l}\text { Yes } \\
\text { No }\end{array}$ & $\begin{array}{l}23.2 \% \\
76.7 \%\end{array}$ & $N=73$ \\
\hline $\begin{array}{l}\text { Are you satisfied with the product purchased as } \\
\text { part of „up-selling”? }\end{array}$ & $\begin{array}{l}\text { Yes } \\
\text { No }\end{array}$ & $\begin{array}{l}47.6 \% \\
52.4 \%\end{array}$ & $\mathrm{~N}=21$ \\
\hline
\end{tabular}


Table 4. Answers to selected...

\begin{tabular}{|c|c|c|c|}
\hline If you are not satisfied: why? & $\begin{array}{l}\text { The product turned out to be } \\
\text { different than offered } \\
\text { The product turned out to be } \\
\text { unnecessary } \\
\text { The product turned out to be } \\
\text { expensive }\end{array}$ & $\begin{array}{l}2 \\
3 \\
4\end{array}$ & $\begin{array}{l}\mathrm{N}=9 \\
\text { (multiple } \\
\text { choice) }\end{array}$ \\
\hline $\begin{array}{l}\text { Has the use of "up-selling" had a positive or } \\
\text { negative impact on your perception of a bank that } \\
\text { tried to sell its products in this way? }\end{array}$ & $\begin{array}{l}\text { Positive } \\
\text { Negative } \\
\text { It had no effect }\end{array}$ & $\begin{array}{l}13.4 \% \\
29.9 \% \\
56.7 \%\end{array}$ & $N=67$ \\
\hline $\begin{array}{l}\text { Has the use of "up-selling” ever maked changed } \\
\text { the bank that you used? }\end{array}$ & $\begin{array}{l}\text { Yes } \\
\text { No }\end{array}$ & $\begin{array}{l}8.7 \% \\
91.3 \%\end{array}$ & $N=69$ \\
\hline $\begin{array}{l}\text { Do you think that up-selling may infringe con- } \\
\text { sumer rights? }\end{array}$ & $\begin{array}{l}\text { Yes } \\
\text { No }\end{array}$ & $\begin{array}{l}46.5 \% \\
53.5 \%\end{array}$ & $N=144$ \\
\hline
\end{tabular}

S o u r c e : author's own survey.

The purpose of the survey, which was carried out on bank customers, was to check whether the use of cross-selling or up-selling influences the perception of the bank by its clients. For this purpose, it was necessary to determine whether customers are satisfied with the products purchased in this way and how it affected the perception of the bank. The results obtained indicate that in the case of cross-selling, 51\% of the bank's customers surveyed, who benefited from the cross-selling purchase, are not satisfied with the product purchased in this way. The main reason is that this product turns out to be unnecessary to customers. Showing benefits, especially financial ones, resulting from the use of cross-selling means that customers buy this product, but eventually it turns out to be unnecessary. The second reason why customers are not satisfied with products purchased as part of cross-selling is their price. Often, it turns out that a product purchased separately is not more expensive than a cross-selling one or the difference is small that it leads to dissatisfaction of customers. Another reason reported by 5 clients out of 23 who have used cross-selling and are not happy about it is the product's non-compliance with the offer. Customers complain that the bank's offer presented by its employees is sometimes inconsistent with the actual state, for example, fees are hidden. This is a negative news, especially as the reasons for dissatisfaction described by customers may be the result of misselling and unethical sales.

Half of the bank's customers, who answered the question about the impact of cross-selling on their perception of the bank, believes that cross-selling did not have any impact on their perception of the institution. However, every third 
responding person believes that offering a cross-selling product had a negative impact on the perception of the bank. This is a large percentage of clients, the more that nearly $12 \%$ of people who answered the question about satisfaction with a cross-selling product admits that as a result of dissatisfaction changed their original bank. This means that the use of cross-selling can cause not only customer dissatisfaction, which affects the negative perception of the institution, but also cause the loss of the client in favor of another, competitive bank. There are also people who positive perception of the bank, but this group represents only $16 \%$ of those who answered the question about satisfaction with the cross-selling product.

In the case of customers who bought products offered as part of up-selling, more than half of them, as much as $52 \%$, are not satisfied with this purchase. The main reason is price. It turns out that customer dissatisfaction is mainly due to the high price of the product, as well as the costs generated by its use or possession. In addition, the additional benefits indicated by the bank's employees, which the customer will gain when purchasing a given product, as well as a wider scope of its functions, are finally unnecessary. Customers do not notice that a product bought as part of up-selling meets more of their needs or does not use its additional functions. In addition, in the case of up-selling, you can sometimes notice the incompatibility of the product with the offer presented by a bank employee, which also contributes to his dissatisfaction. This is a negative news due to the fact that the reasons presented by customers may be the result of misseling and unethical sales.

For more than half of the customers who answered the question about satisfaction with the product purchased under up-selling, its sales had no impact on their perception of the bank. However, almost 30\% of them admit that offering the product in this way had a negative impact on the perception of the institution. Additionally, 9\% of the 69 customers admit to changing the bank, which was influenced by the use of up-selling. Only $13 \%$ of the 67 respondents agree to the positive impact of this technique on bank perception. This means that up-selling, like cross-selling, can also cause dissatisfaction among some customers and contribute to the change of their bank, but to a lesser extent than in the case of bundling.

In addition, in order to draw additional conclusions from the study, the Pearson's linear correlation coefficient was used between two questions contained in the questionnaire and the gender of respondents. This coefficient determines the level of linear dependence between random variables. In this case, the gen- 
der of respondents and their willingness to take advantage of products offered as part of cross-selling and up-selling were taken into account. The Pearson coefficient in both cases came out negative. The correlation between the gender of respondents and the tendency to use products offered as part of cross-selling is weak and amounted to approximately -0.3. Correlation between the gender of respondents and the tendency to take advantage of products offered as part of up-selling is weak and amounted to approximately -0.19. This means there is no dependency between selected random variables. None of the sexes is more likely to use the products offered under the above sales techniques.

Cross selling and up selling in the opinion of customers can often violate the law. There is a suspicion that the use of these techniques may violate consumer rights. Cross selling and up selling is associated with selling products that are actually unnecessary to customers. In addition, in the case of bundling, the price of the products is the same as when purchased separately. In the case of up-selling, products with a higher price are sometimes not equipped with additional, higher functionality. This raises doubts as to the integrity of these practices. A positive aspect is the fact that the problem of the integrity of crossselling has been noticed. In 2016, guidelines on good practices for tying were established at the European Union level. Perhaps over the years, both bundled and additional sales will be regulated, thanks to which banks will start to be perceived in a more positive way.

\section{REFERENCES}

Baumgarten, J., Widz, A., Białokozowicz, P., \& Dietl, M. (2006). Łączenie ofert w sektorze bankowym. (Combining offers in the banking sector.) Gazeta Bankowa, 17.

European Securities and Markets Authority (2016). Wytyczne dotyczace praktyk sprzedaży krzyżowej. (Guidelines on cross-selling practices.) ESMA/2016/574 PL.

Johnson, J.S., \& Friend, S. (2014). Contingent cross-selling and up-selling relationships with performance and job satisfaction: an MOA-theoretic examination. Journal of Personal Selling \& Sales Management, 35(1), 51-71. https://dx.doi.org/10.1080/0 8853134.2014.940962.

Kaleta, A. (2013). Realizacja strategii. (Implementation of the strategy.) Warszawa: Polskie Wydawnictwo Ekonomiczne.

Kubiak, B.F., \& Weichbroth, P. (2010). Cross- And Up-selling Techniques In E-Commerce Activities. Gdańsk: Journal of Internet Banking and Commerce.

Mikołajczyk, Z. (1997). Techniki organizatorskie w rozwiq̨zywaniu problemów zarządzania. (Organizational techniques in solving management problems.) Warszawa: Wydawnictwo Naukowe PWN. 
Paradecki, R. (2008). Wpływ współzależności produktów bankowych na wynik ze sprzedaży i cykl życia. (Influence of the interdependence of banking products on the result on sales and life cycle.) Prace Naukowe Uniwersytetu Ekonomicznego we Wrocławiu, (Research Papers of Wrocław University of Economics.) 14, 340-348.

Próchnicki, W. (2014). Cross selling i up selling - strategie sprzedaży. (Cross selling i up selling - sales strategies.) Poznań: Szef Sprzedaży 14/2014.

Supernat, J. (2000). Techniki decyzyjne i organizatorskie: wydanie I. (Decision making and organizational techniques: edition I.) Wrocław: Lord Kass.

Szczepaniec, M. (2003). Sprzedaż krzyżowa produktów bankowych. (Cross-selling of banking products.) Bank i Kredyt, (Bank and Credit.) 3, 95-101. 